\title{
TITLE:
}

\section{PALINURID AND SCYLLARID LOBSTERS (CRUSTACEA DECAPODA) FROM NEW CALEDONIA}

$\operatorname{AUTHOR(S):~}$

Harada, Eiji

CITATION:

Harada, Eiji. PALINURID AND SCYLLARID LOBSTERS (CRUSTACEA DECAPODA) FROM NEW CALEDONIA. PUBLICATIONS OF THE SETO MARINE BIOLOGICAL LABORATORY 1961, 9(1): 191-196

\section{ISSUE DATE:}

1961-05-30

URL:

http://hdl.handle.net/2433/174657

RIGHT: 


\title{
PALINURID AND SCYLLARID LOBSTERS (CRUSTACEA DECAPODA) FROM NEW CALEDONIA ${ }^{1,2}$
}

\author{
EIJI HARADA
}

Seto Marine Biological Laboratory, Sirahama

With Plate VI and 3 Text-figures

The Palinurid and Scyllarid lobsters, obtained during the Melanesia Expedition of the Ósaka Museum of Natural History in 1958, were sent to me for examination through the kindness of Dr. T. Tokioka of our Laboratory. This collection comprises only three species, Scyllarides squamosus (H. MiLNE Edwards), Parribacus caledonicus Holthuis and Panulirus penicillatus (Olivier), the second of which has just been described by Dr. L. B. Holthuis (1960) as a new species from the same locality.

\section{Scyllarides squamosus (H. MiLNE EDWARDS)}

(Text-fig. 1)

Material: a carapace fragment of unknown sex, stranded at Poum (carapace length approximately $55 \mathrm{~mm}$ ).

The carapace is covered with coarse tubercles and has three protuberances, the anterior one of which is situated on the dorsal side of the rostrum. Three spines are present on the dorsal edge of the orbit. The antennular tergum is provided with two sharp spines at the median of the anterior edge, which are projecting out obliquely upwards. The nner edges of the 1st to 3rd segments of the antenna are erected upwards and are furnished with sharp spines. The anterior margin of the 2nd segment of the antenna is serrated; but without any large teeth. A spinous process is present at the middle of the dorso-anterior margin of the 1st segment of the antenna. The epistome has two pairs of strong teeth near the middle of its anterior edge.

1) Scientific Results of the Melanesia Expedition No. 10.

2) Contributions from the Osaka Museum of Natural History, No. 70 and Contributions from the Seto Marine Biological Laboratory, No. 364 .

Publ. Seto Mar. Biol. Lab., IX (1), 1961. (Article 10) 
This specimen resembles closely Scyllarides squamosus (H. Milne Edwards) from the Japanese waters, but, in the former, the tubercles and bosses on the carapace are a little rougher and stronger, spines on the inner margins of the antennal segments are sharper, and a tooth situated near the inner dorso-anterior corner of the 2nd segment of the antenna is less conspicuous than in the latter.

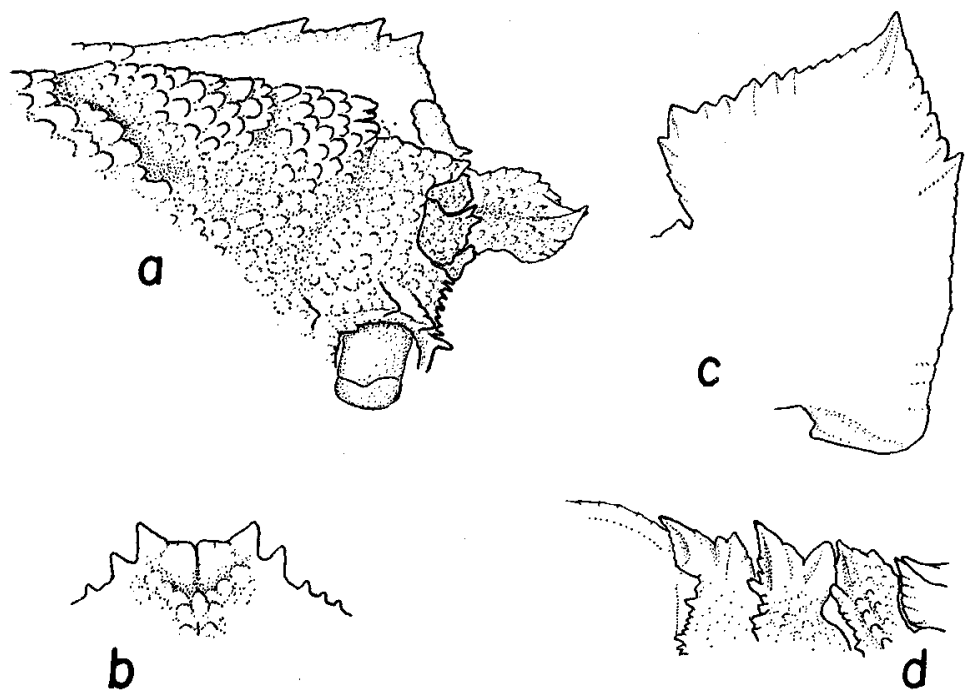

Fig. 1. Scyllarides squamosus (H. MILNE EDWARDS). $a$, dorso-lateral view of the anterior part of the carapace; $b$, ventral view of the epistome; $c$, dorsal view of the 2nd segment of the antenna; $d$, dorso-lateral view of the inner edges of the antennal segments.

\section{Parribacus caledonicus HoLthuIS}

(Text-fig. 2; Pl. VI)

Material: 1 female (carapace length $37 \mathrm{~mm}$ ) from Ilot Maitre; 1 male (carapace length $48 \mathrm{~mm}$ ) and 1 female (carapace length $38 \mathrm{~mm}$ ) from Ile des Pins; 1 male (carapace length $36 \mathrm{~mm}$ ) from the Outer Reef of Ile des Pins.

The carapace is broadest at the level of the 3rd or the 4th lateral tooth. The ratio of the total length* of the carapace to its width is approximately $2 / 3$. The dorsal staface of the carapace is hairy. The incision between the two anterolateral teeth of the carapace is shallow. The rostrum is provided with a short tubercular spinules on its dorsal side. Heavy squamiform sculpturing is present on the abdominal tergites. Anterior parts of the 2nd to 4 th abdominal tergites are covered with light squamiform sculpturing. The median carina is distinctly

* The length from the tip of the rostrum to the posterior end of the carapace. 
marked out on 2nd and 3rd abdominal tergites. A pair of small spines on the anterior margin of the epistome are rather blunt. The 5 th thoracic sternite bears a pair of small tubercular prominences in male. The distal segment of the antenna is armed with 8 teeth on its anterior margin, and the 2nd segment is provided with 7 sharp teeth (the terminal tooth not included) on its lateral margin. These

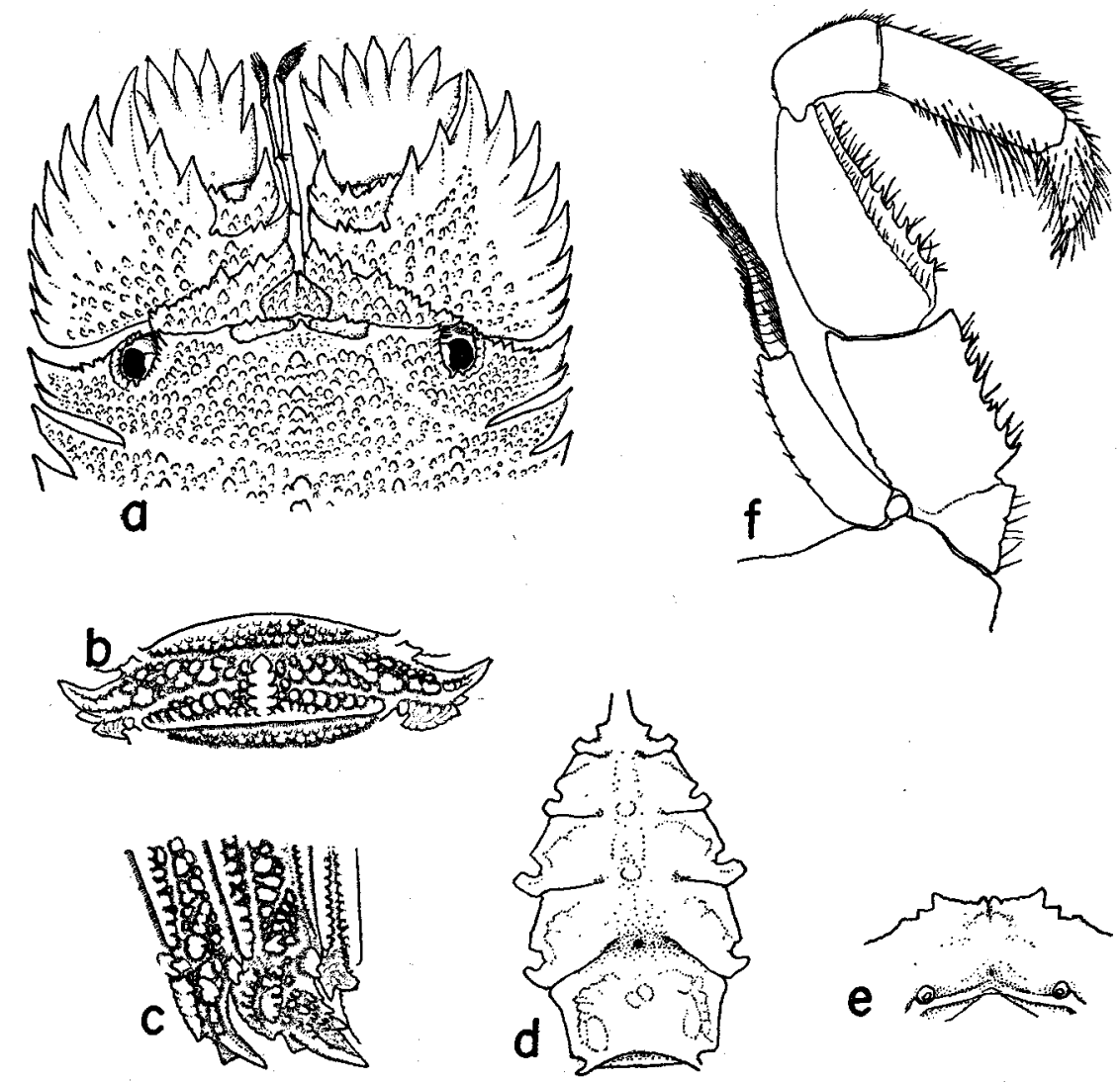

Fig. 2. Parribacus caledonicus HolthuIs.

$a$, dorsal view of the antennae and anterior part of the carapace; $b$, dorsal view of the 3rd abdominal segment; $c$, lateral view of the pleurons of 2 nd and 3rd abdominal segments; $d$, ventral view of the thoracic sternum (male). $(\times 1.7) ; e$, ventral view of the epistome $(\times 1.7)$; ventral view of the 3 rd maxilliped $(\times 4.3)$.

teeth are marked each with a round white spot on both dorsal and ventral sides. A dark blue band is found girding transversely each segment of the pereiopods. Dark blue spots on the ventral surface of the carapace and thoracic and abdominal sternites are rather inconspicuous as compared with those found on Parribacus japonicus HoLthuIs. 

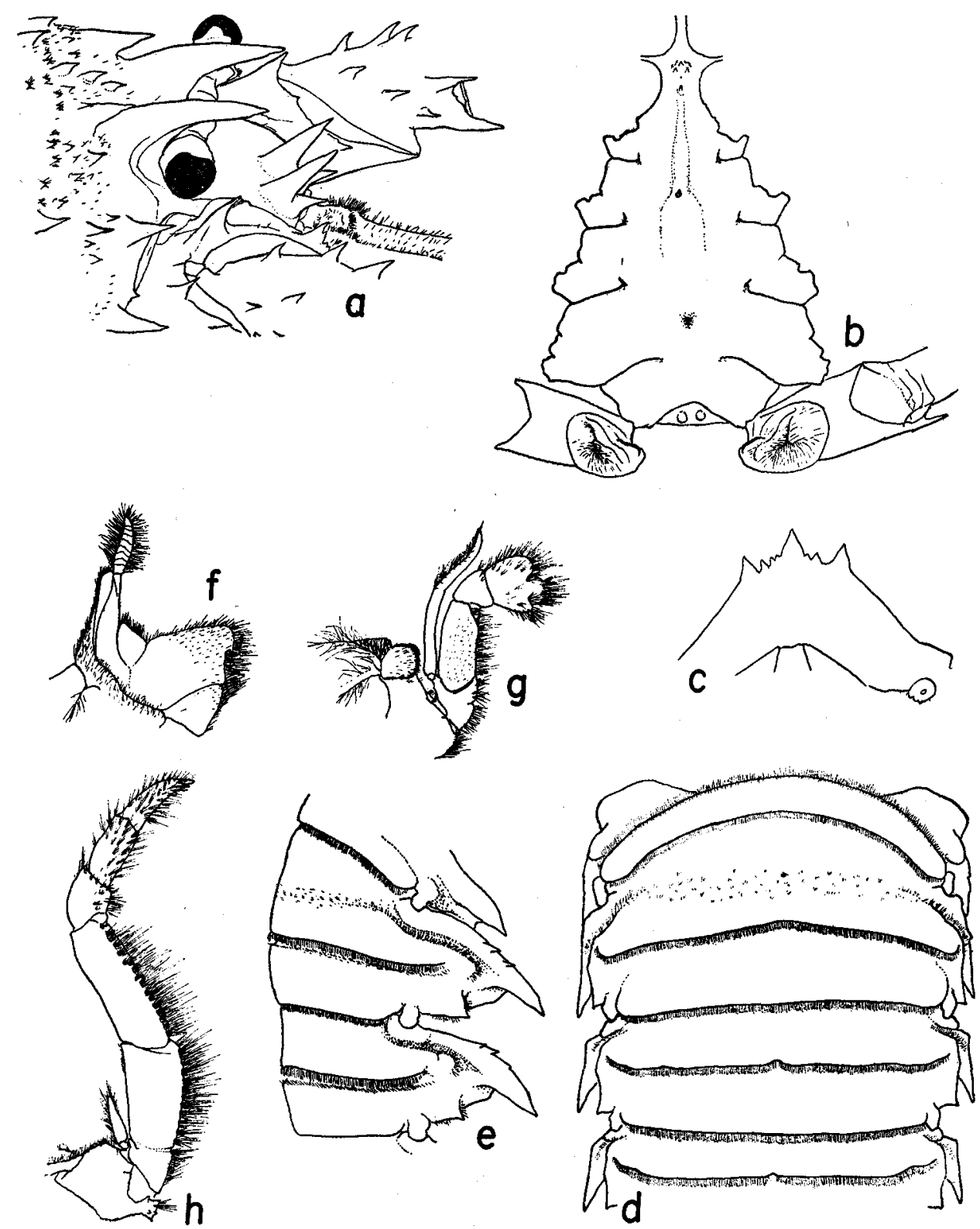

Fig. 3. Panulirus penicillatus (OLIVIER).

$a$, dorso-lateral view of the anterior part of the carapace; $b$, ventral view of the thoracic sternum; $c$, ventral view of the epistome; $d$, dorsal view of the 1 st to 4th abdominal segments; $e$, lateral view of the 2 nd and 3rd abdominal segments; $f$, ventral view of the 1st maxilliped; $g$, ventral view of the 2nd maxilliped; $h$, ventral view of the $3 r d$ maxilliped. 


\section{Panulirus penicillatus (OLIVIER)}

(Text-fig. 3)

Material: 1 male (carapace length $89 \mathrm{~mm}$ ) from the Outer Reef of Ile des Pins; fragments of a carapace of unknown sex, stranded at Moneo.

The carapace is thickly covered with spines and spinules, the latter of which are fringed anteriorly by short stiff hairs. The transverse cervical groove and the transverse groove near the posterior edge of the carapace are both deep. The supraorbital spines are long and strong, and are spaced rather narrowly. Three short spines are present on the median line of the carapace just behind its anterior edge. The antennular tergum bears two pairs of strong spines, of which two on the same side are coalesced at their bases. The dorsal margin of the distal end of the 1st segment of the antenna is armed with a sharp spine and small blunt spinules. The ventral margin of the same part is with blunt spinules. The 1st segment of the antennule, which is twice as long as two following segments, is not longer than half of the carapace length. Transverse grooves on the abdominal tergites are complete and deep, and are concaved slightly forwards. Anterior margins of abdominal tergal lobes bear spinules. The posterior margin of the 6th abdominal tergite is furnished with shap spinules; hairs fringing this part are not so long as in Panullirus versicolor (LATREILLE). Spinules on the dorsal surface of the telson are not so sharp as in Panulirus versicolor (LATREILIE). The epistome is armed with sharp spinules on its anterior margin. The 5th thoracic sternite is provided with a pair of blunt tubercular protuberances near its posterior margin. The 3rd maxilliped has a short expodite half as long as the ischium. Pereiopods are furnished longitudinally with white stripes.

\section{REFERENCES}

BALss, H. 1914. Ostasiatische Decapoden. II. Die Natantia und Reptantia. Abh. Bayer. Akad. Wiss., suppl. vol. 2, pt. 10, 101 pp., 52 textfigs., 1 pl.

BATE, C. S. 1888. Report on the Crustacea Macrura collected by H. M. S. "Challenger" during the years 1873-76. Rep. Voy. "Challenger", Zool., vol. 24, pp. i-xc+1-942, textfigs. 1-76, pls. 1-150. London.

Forest, J. 1954. Crustacés Décapodes Marcheurs des Iles de Tahiti et des Tuamotu. II. Scyllaridea. Bull. Mus. Hist. nat. Paris, ser. 2, vol. 27, no. 3, pp. 345-352.

Gruvel, A. 1911. Contribution à l'étude général systématique des Palinuridae. Ann. de l'Inst. Océanogr., vol. 3, pt. 4, 56 pp., 6 pls.

HaAN, W. DE 1841. Crustacea. In : P. F. de Siebold's Fauna Japonica, pp. 1-244, pls. 1-55+A-Q. Leiden.

HolthuIs, L. B. 1947. Biological results of the Snellius Expedition. XIV. The Decapoda Macrura of the Snellius Expedition. 1. The Stenopodidae, Nephropsidae, Scyllaridae and Palinuridae. Temminckia, vol. 7 , pp. 1-178, pls. 1-11.

1960. Preliminary descriptions of one new genus, twelve new species and three new subspecies of Scyllarid lobsters (Crustacea Decapoda Macrura). Proc. Biol. Soc. Wash., vol. 73 , pp. 147-154. 
Kubo, I. 1954. Systematic studies on the Japanese Macrurous Decapod Crustacea. 3. On the Palinurid lobsters. Journ. Tokyo Univ. Fish., vol. 41, no. 1, pp. 95-105, pls. 1-6.

MAN, J. G. DE 1916. The Decapoda of the Siboga Expedition. III. Families Eryonidae, Palinuridae, Scyllaridae and Nephropsidae. Mon. Siboga-Expeditie, mon. $39 \mathrm{a}^{2}, 122$ pp., 4 pls. Leiden.

Stebbing, T. R. R. 1910. General catalogue of South African Crustacea, Cape Town. Ann. S. Afr. Mus., vol. 6, pt. 4, pp. 281-593, pls. 15-22.

\section{EXPLANATION OF PLATE VI}

Parribacus caledonicus HolthuIs.

Fig. 1. Dorsal view of a male.

Fig. 2. Ventral view of a female.

Fig. 3. Lateral view of the abdomen of a female. 


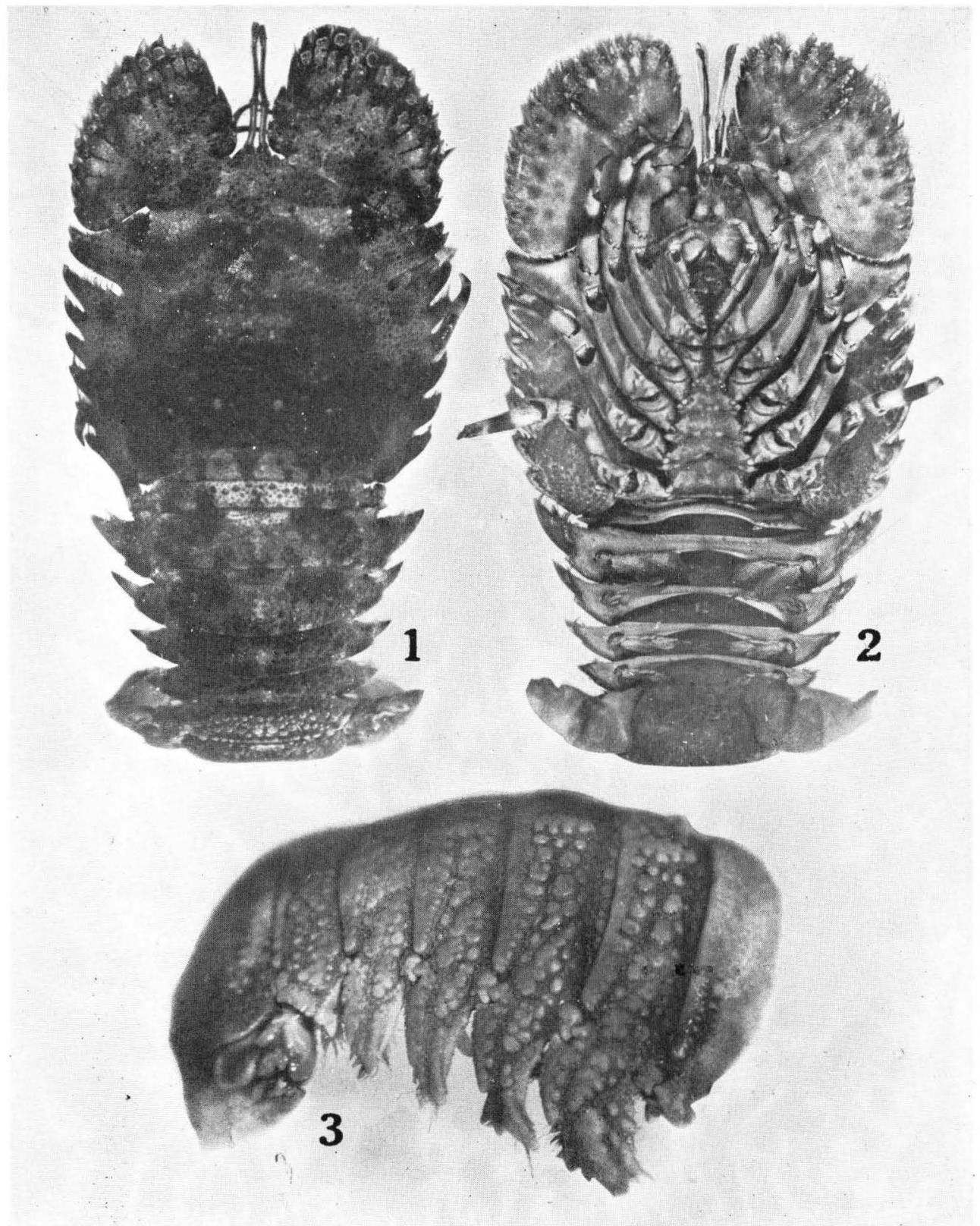

E. Harada: Palinurid and Scyllarid Lobsters from New Caledonia. 